\title{
PERBANDINGAN KEJADIAN DAN TINGKAT DEPRESI GURU HONORER DI SEKOLAH DASAR NEGERI PADA EMPAT KECAMATAN DI KOTA KOTAMOBAGU PROVINSI SULAWESI UTARA
}

\author{
${ }^{1}$ Ratih K.D Arfa \\ ${ }^{2}$ L.F.J Kandou \\ ${ }^{2}$ Herdy Munayang
}

\begin{abstract}
Kandidat Skripsi Fakultas Kedokteran Universitas Sam Ratulangi ${ }^{1}$ Bagian Psikiatri Fakultas Kedokteran Universitas Sam Ratulangi ${ }^{2}$

Email: ratzdbestofme@yahoo.fr
\end{abstract}

\begin{abstract}
Abstrak: Perbandingan kejadian dan tingkat depresi guru honorer di Sekolah Dasar Negeri pada empat Kecamatan di Kota Kotamobagu Provinsi Sulawesi Utara. Pendahuluan: Depresi merupakan gangguan mood yang paling sering dikaitkan dengan stres pekerjaan yang dimiliki individu dalam lingkungan pendidikan seperti profesi guru. Gejala depresi yang dialami guru sering dihubungkan dengan jenis kelamin, umur, status pernikahan, rendahnya kepuasan terhadap profesi, gaji atau penghargaan, keinginan untuk merubah pekerjaan, serta dukungan sosial. Di Indonesia, guru honorer yang memiliki status kepegawaian yang tidak jelas rentan mengalami depresi. Penelitian ini bertujuan untuk mengetahui perbandingan kejadian dan tingkat depresi guru honorer di Sekolah Dasar Negeri pada empat Kecamatan di Kota Kotamobagu Provinsi Sulawesi Utara. Metode: Penelitian ini bersifat observasional-analitik dengan pendekatan cross-sectional. Penelitian ini melibatkan seluruh guru honorer yang mengajar di tiap Sekolah Dasar Negeri di empat Kecamatan dengan total 102 responden. Instrumen penelitian ialah kuesioner sosiodemografi dan Hamilton Depression Rating Scale (HDRS). Analisis univariat dan bivariat (Chi square test) dilakukan dengan menggunakan aplikasi komputer. Hasil:Proporsi depresi di Kecamatan Kotamobagu Timur (84,8\%) lebih besar daripada proporsi depresi di Kecamatan Kotamobagu Utara (80\%), Kecamatan Kotamobagu Barat (82,8\%) dan Kecamatan Kotamobagu Selatan (83,3\%). Uji beda kejadian dan tingkat depresi mendapatkan nilai $\mathrm{p}=0,986$ dan $\mathrm{p}=0$,989.Simpulan: Tidak terdapat perbedaan yang bermakna antara kejadian dan tingkat depresi guru honorer di Sekolah Dasar Negeri pada empat Kecamatan di Kota Kotamobagu Provinsi Sulawesi Utara.
\end{abstract}

Kata Kunci: perbandingan, depresi, guru honorer, HDRS

\begin{abstract}
The comparison of prevalence and degree of depression among honorary teachers in Public Primary Schools of four Districts in Kotamobagu City, North Sulawesi. Introduction: Depression is a mood disorder that mostly related to the occupational stress among people involved in educational environment especially teacher profession. Depressive symptoms felt by teacher is usually correlated with gender, age, marital status, low job satisfaction, salary or reward, wish to change a job, and social support. In Indonesia, honorary teachers who have a non-confirmed status of teaching tend to be stress and furthermore being more depressive to face these job conditions. This research aimed to examine the comparison of prevalence and degree of depression among honorary teachers in Public Primary Schools of four Districts in Kotamobagu City, North Sulawesi. Method: This research was a cross-sectional study that used observational-analytic design. This study involved 102 honorary teachers, teaching in all Public Primary Schools of four Districts in Kotamobagu. The instruments used in this research were Socio-demographic and Hamilton Depression Rating Scale (HDRS) questionnaires.
\end{abstract}


Univariate and bivariate analysis (Chi Square test) were done with a computer application program. Result: The proportion of depression of East Kotamobagu district (84,8\%) was greater than in North Kotamobagu District (80\%), West Kotamobagu District (82,8\%) and South Kotamobagu district (83,3\%). Prevalence and degree comparation got p score 0,986 and 0,989. Conclusion:There are no significant prevalence and degree differences of depression among honorary teachers in Public Primary Schools of four districts in Kotamobagu City, North Sulawesi.

Keywords: depression, comparison, honorary teachers, HDRS

Guru menurut kamus besar bahasa Indonesia adalah orang yang pekerjaan, mata pencaharian, atau profesinya mengajar, sedangkan menurut undang-undang no 14 tahun 2005 tentang pasal 1 ayat 1 adalah pendidik professional dengan tugas utama mendidik, mengajar, membimbing, melatih dan mengevaluasi peserta didik dan pendidikan anak usia dini jalur pendidikan formal, pendidikan dasar dan pendidikan menengah. ${ }^{1,2}$ Peran guru sangat bermakna terhadap dunia pendidikan karena selain menyampaikan ilmu pengetahuan, guru juga berperan dalam memberikan pendidikan karakter guna perkembangan moral anak didiknya, sangat ironis ketika melihat peran tersebut tidak sebanding dengan kesejahteraan terutama guru honorer di Indonesia. Masalah yang paling sering dihadapi dihadapi guru honorer terutama honorarium per bulan ataupun pengakuan menjadi guru tetap. Masalah yang dihadapi guru honorer bisa menimbulkan stres yang dapat berujung pada suatu perasaan depresi. ${ }^{3,4,5}$

Depresi adalah suatu gangguan suasana perasaan (mood) yang mempunyai gejala utama afek depresi, kehilangan minat dan kegembiraan, dan kekurangan energi yang berakibat meningkatnya keadaan mudah lelah dan menurunnya aktifitas. Gejala lain depresi yaitu konsentrasi dan perhatian berkurang, pikiran bersalah dan tidak berguna, pandangan masa depan yang suram dan pesimistis, gagasan atau perbuatan membahayakan diri atau bunuh diri, tidur terganggu dan nafsu makan berkurang. ${ }^{6}$ Secara global diperkirakan depresi terjadi pada 340 juta jiwa. ${ }^{7}$ Depresi berdasarkan tingkat penyakitnya dibagi menjadi tiga jenis yaitu depresi ringan, depresi sedang dan depresi berat. Di negara-negara berkembang, World Health Organization (WHO) memprediksi pada tahun 2020 depresi akan menjadi penyebab kedua terbesar kematian setelah serangan jantung. Hasil survei Perhimpunan Dokter Spesialis Kedokteran Jiwa Indonesia (PDSKJI) pada Juni 2007 menyebutkan sekitar 94 persen masyarakat Indonesia mengidap depresi dari mulai depresi ringan sampai depresi berat. ${ }^{8}$

Menurut Kyriacou depresi guru termasuk dalam kategori stres, hal yang dialami merupakan pengalaman yang bersifat tidak menyenangkan serta emosi negatif yang diakibatkan sejumlah aspek dalam kehidupannya terutama dalam lingkungan kerja sebagai guru. ${ }^{9}$ Penelitian di Amerika Serikat menunjukkan adanya korelasi yang bermakna antara depresi, kepuasan terhadap pekerjaan serta motivasi pada individu yang berprofesi sebagai guru. Satu dari sepuluh individu yang bekerja dalam lingkungan pendidikan seperti guru diperkirakan mengalami episode depresi dalam hidup mereka. Perempuan $(9,6 \%)$ lebih rentan mengalami depresi daripada laki-laki (6,3\%) dan umur 35-49 tahun paling tinggi memiliki risiko mengalami depresi. ${ }^{10,11}$ Menurut studi yang dilakukan oleh Resilience Education, guru seringkali meninggalkan profesinya karena perasaan depresi yang dialami. ${ }^{12}$ National Center of Education Statistic juga melaporkan sekitar $50 \%$ dari guru meninggalkan profesinya setelah hampir 5 tahun mengajar. Hal ini diduga disebabkan karena stres yang dialami di lingkungan Sekolah ataupun alasan kebutuhan finansial. ${ }^{13}$ 
Di Indonesia, kondisi guru honorer cenderung memprihatinkan. Guru honorer harus menerima bahwa insentif ataupun gaji yang mereka terima tidak sebanding dengan tanggung jawab untuk mendidik siswa secara akademik maupun dari segi tingkah lakunya. Guru honorer hanya mendapatkan honorarium per bulan, cuti dan perlindungan hukum,selain daripadaitu, mereka tidak mendapatkan fasilitas yang sama dengan guru tetap lainnya.Masa depannya pun kurang jelas karena status kepegawaiannya. ${ }^{14}$

Penelitian yang mengambil subjek guru honorer di Kota Kotamobagu Provinsi Sulawesi Utara ini, secara umum bertujuan untuk menilai perbandingan prevalensi depresi guru honorer di Sekolah Dasar (SD) Negeri pada empat Kecamatan yang ada di Kota Kotamobagu dan secara khusus mengetahui kejadian serta tingkat depresi di tiap Kecamatan serta mengetahui kejadian depresi berdasarkan karakteristik yang dimiliki responden (umur, jenis kelamin, status pernikahan, masa kerja, honorarium per bulan, pendapatan tambahan, jam kerja per hari).

\section{METODE}

Penelitian ini bersifat observasionalanalitik dengan pendekatan cross sectional. Subjek penelitian yang termasuk dalam populasi target penelitian ialah seluruh guru honorer yang mengajar di SD Negeri pada empat Kecamatan di Kota Kotamobagu Provinsi Sulawesi Utara dengan total keseluruhan 102 responden. Kriteria inklusi penelitian ialah guru honorer yang terdaftar secara sah di sejumlah SD Negeri pada masing-masing Kecamatan dan bersedia untuk menjadi subjek penelitian, sedangkan kriteria eksklusinya yaitu guru honorer yang tidak sempat hadir saat pengambilan data karena sakit atau mendadak ada halangan penting. Data merupakan data primer yang dikumpulkan pada bulan pada bulan November-Desember 2012. Responden yang bersedia untuk dijadikan subjek penelitian dibagikan lembaran informed consentsebagai persetujuan penelitian kemudian kuesioner sosiodemografi yang menyangkut data pribadi responden dan beberapa pertanyaan seputar profesinya, selanjutnya kuesioner HDRS untuk menilai derajat depresi responden baik ringan, sedang, maupun berat.Pengolahan data dilakukan dengan program komputer meliputi analisis univariat (distribusi frekuensi) dan analisis bivariat untuk mengetahui perbedaan kejadian dan tingkat depresi responden dari empat Kecamatan yang berbeda (Chi Square test).

\section{HASIL DAN PEMBAHASAN}

Pada tabel 1 dan 2 didapatkan bahwa di Kecamatan Kotamobagu Utara responden yang tidak mengalami depresi 2 orang (20\%) dan mengalami depresi yaitu 8 orang (80\%; 40\% depresi ringan, 30\% depresi sedang, dan 10\% depresi berat).Di Kecamatan Kotamobagu Selatan responden yang mengalami depresi 25 orang (83,3\% ; $60 \%$ depresi ringan, 20\% depresi sedang, dan 3,3\% depresi berat ), sedangkan tidak mengalami depresi 5 orang (16,7\%). Di Kecamatan Kotamobagu Barat yang mengalami depresi 24 orang (82,8\%; 58,6\% depresi ringan, 20,7\% depresi sedang, dan $3,4 \%$ depresi berat) sedangkan yang tidak mengalami depresi 5 orang $(17,2 \%)$. Di Kecamatan Kotamobagu Timur yang mengalami depresi 28 orang (84,8\%; 60,6\% depresi ringan, 18,2\% depresi sedang,dan 6,1\% depresi berat) dan tidak mengalami depresi 5 orang $(15,2 \%)$.

Tabel 1. Kejadian depresi pada empat Kecamatan di Kota Kotamobagu

\begin{tabular}{llll}
\hline Kecamatan & & $\mathbf{n}$ & $\mathbf{( \% )}$ \\
\hline Kotamobagu & Depresi & 8 & $80 \%$ \\
utara & Tidak depresi & 2 & $20 \%$ \\
\cline { 2 - 4 } Kotamobagu & Depresi & 25 & $83,3 \%$ \\
selatan & Tidak depresi & 5 & $16,7 \%$ \\
\cline { 2 - 4 } Kotamobagu & Depresi & 24 & $82,8 \%$ \\
barat & Tidak depresi & 5 & $17,2 \%$ \\
\cline { 2 - 4 } Kotamobagu & Depresi & $28 \%$ & $84,8 \%$ \\
timur & Tidak depresi & 5 & $15,2 \%$ \\
\hline
\end{tabular}


Tabel 2. Tingkat depresi pada empat Kecamatan di Kota Kotamobagu

\begin{tabular}{llccc}
\hline Kecamatan & \multicolumn{4}{c}{ Tingkat depresi } \\
\hline & & $\begin{array}{c}\text { Depresi } \\
\text { ringan }\end{array}$ & $\begin{array}{c}\text { Depresi } \\
\text { sedang }\end{array}$ & $\begin{array}{c}\text { Depresi } \\
\text { berat }\end{array}$ \\
\hline Kotamobagu & $\mathrm{n}$ & 4 & 3 & 1 \\
utara & $\%$ & $40 \%$ & $30 \%$ & $10 \%$ \\
\cline { 2 - 5 } Kotamobagu & $\mathrm{n}$ & 20 & 6 & 2 \\
timur & $\%$ & $60,6 \%$ & $18,2 \%$ & $6,1 \%$ \\
\cline { 2 - 5 } Kotamobagu & $\mathrm{n}$ & 17 & 6 & 1 \\
barat & $\%$ & $58,6 \%$ & $20,7 \%$ & $3,4 \%$ \\
Kotamobagu & $\mathrm{n}$ & 18 & 6 & 1 \\
selatan & $\%$ & $60 \%$ & $20 \%$ & $3,3 \%$ \\
\hline
\end{tabular}

Pada tabel 3 didapatkan distribusi kejadian depresi berdasarkan karakter responden. Di Kecamatan Kotamobagu Utara perempuan lebih rentan mengalami depresi daripada laki-laki (83,3\%), dari segi umur yang mengalami depresi dengan rentang keseluruhan 17-52 tahun berada paling banyak pada kelompok usia 44-52 tahun, dari status pernikahan, yang mengalami depresi lebih dominan pada yang sudah menikah. Dari segi pekerjaan, masa kerja di antara 4-8 tahun lebih cenderung mengalami depresi. Dari honorarium per bulan, honorarium $<$ Rp.500.0000 lebih cenderung mengalami depresi. Dari segi pendapatan tambahan di luar mengajar, maka guru honorer yang memiliki usaha sampingan,dan lain-lain cenderung mengalami depresi serta jam kerja yang dimiliki baik 1-3 jam atau 4-6 jam berada pada posisi yang sama dalam hal kecenderungan mengalami depresi. Berdasarkan tabel 4 Di Kecamatan Kotamobagu Selatan, perempuan lebih rentan mengalami depresi (87\%), dari segi kelompok umur, usia 17-25 tahun lebih dominan mengalami depresi, dari status pernikahan yang mengalami depresi cenderung yang belum menikah. Dari segi pekerjaan, masa kerja 1-3 tahun lebih rentan mengalami depresi. Dari honorarium per bulan dan ada atau tidaknya pendapatan tambahan, maka yang lebih rentan mengalami depresi ialah yang tidak memiliki pendapatan atau usaha tambahan dan dari segi jam kerja yang lebih rentan mengalami depresi ialah individu yang memiliki jam kerja 1-3 jam/hari.

Tabel 3. Kejadian depresi berdasarkan karakteristik responden di Kec. Kotamobagu Utara

\begin{tabular}{llcc}
\hline Variabel & & n & \% \\
\hline Umur & & & \\
& & & \\
$17-25$ & Tidak depresi & 2 & $66,7 \%$ \\
& Depresi & 1 & $33,3 \%$ \\
$26-34$ & Tidak depresi & 0 & $0 \%$ \\
& Depresi & 1 & $100 \%$ \\
$35-43$ & Tidak depresi & 0 & $0 \%$ \\
& Depresi & 2 & $100 \%$ \\
$44-52$ & Tidak depresi & 0 & $0 \%$ \\
& Depresi & 4 & $100 \%$ \\
\hline Jenis kelamin & & & \\
\multirow{2}{*}{ Laki-laki } & Tidak depresi & 1 & $25 \%$ \\
& Depresi & 3 & $75 \%$ \\
Perempuan & Tidak depresi & 1 & $16,7 \%$ \\
& Depresi & 5 & $83,3 \%$ \\
\hline
\end{tabular}

\begin{tabular}{|c|c|c|c|}
\hline $\begin{array}{l}\text { Status } \\
\text { pernikahan }\end{array}$ & & & \\
\hline Belum menikah & Tidak depresi & 2 & $66,7 \%$ \\
\hline & Depresi & 1 & $33,3 \%$ \\
\hline Menikah & Tidak depresi & 0 & $0 \%$ \\
\hline & Depresi & 7 & $100 \%$ \\
\hline Masa kerja & & & \\
\hline 1-3 tahun & Tidak depresi & 2 & $66,7 \%$ \\
\hline & Depresi & 1 & $33,3 \%$ \\
\hline 4-8 tahun & Tidak depresi & 0 & $0 \%$ \\
\hline & Depresi & 6 & $100 \%$ \\
\hline 9-12 tahun & Tidak depresi & 0 & $0 \%$ \\
\hline & Depresi & 1 & $100 \%$ \\
\hline Honorarium & & & \\
\hline$<500000$ & Tidak depresi & 0 & $0 \%$ \\
\hline & Depresi & 4 & $100 \%$ \\
\hline 500000-1000000 & Tidak depresi & 2 & $40 \%$ \\
\hline & Depresi & 3 & $60 \%$ \\
\hline$>1000000$ & Tidak depresi & 0 & $0 \%$ \\
\hline & Depresi & 1 & $100 \%$ \\
\hline $\begin{array}{l}\text { Pendapatan } \\
\text { tambahan }\end{array}$ & & & \\
\hline Tidak & Tidak depresi & 0 & $0 \%$ \\
\hline & Depresi & 3 & $100 \%$ \\
\hline Ya & Tidak depresi & 2 & $28,6 \%$ \\
\hline & Depresi & 5 & $71,4 \%$ \\
\hline Jam kerja/hari & & & \\
\hline 1-3 jam & Tidak depresi & 2 & $33,33 \%$ \\
\hline & Depresi & 4 & $66,7 \%$ \\
\hline 4-6 jam & Tidak depresi & 0 & $0 \%$ \\
\hline & Depresi & 4 & $100 \%$ \\
\hline
\end{tabular}


Tabel 4. Kejadian depresi berdasarkan karakteristik responden di Kec. Kotamobagu Selatan

\begin{tabular}{llcc}
\hline Variabel & & $\mathbf{n}$ & $\mathbf{\%}$ \\
\hline Umur & & & \\
\multirow{2}{*}{$17-25$} & Tidak depresi & 1 & $5,9 \%$ \\
& Depresi & 16 & $94,1 \%$ \\
$26-34$ & Tidak depresi & 2 & $28,6 \%$ \\
& Depresi & 5 & $71,4 \%$ \\
$35-43$ & Tidak depresi & 2 & $40 \%$ \\
& Depresi & 3 & $60 \%$ \\
$44-52$ & Tidak depresi & 0 & $0 \%$ \\
& Depresi & 1 & $100 \%$ \\
\hline
\end{tabular}

\begin{tabular}{|c|c|c|c|}
\hline \multicolumn{4}{|l|}{ Jenis kelamin } \\
\hline \multirow[t]{2}{*}{ Laki-laki } & Tidak depresi & 2 & $28,6 \%$ \\
\hline & Depresi & 5 & $71,4 \%$ \\
\hline \multirow[t]{2}{*}{ Perempuan } & Tidak depresi & 3 & $13 \%$ \\
\hline & Depresi & 20 & $87 \%$ \\
\hline \multicolumn{4}{|l|}{$\begin{array}{l}\text { Status } \\
\text { pernikahan }\end{array}$} \\
\hline \multirow[t]{2}{*}{ Belum menikah } & Tidak depresi & 1 & $6,7 \%$ \\
\hline & Depresi & 14 & $93,3 \%$ \\
\hline \multirow[t]{2}{*}{ Menikah } & Tidak depresi & 3 & $21,4 \%$ \\
\hline & Depresi & 11 & $78,6 \%$ \\
\hline \multirow[t]{2}{*}{ Cerai hidup } & Tidak depresi & 1 & $100 \%$ \\
\hline & Depresi & 0 & $0 \%$ \\
\hline \multicolumn{4}{|l|}{ Masa kerja } \\
\hline \multirow[t]{2}{*}{ 3-6 bulan } & Tidak depresi & 0 & $0 \%$ \\
\hline & Depresi & 8 & $100 \%$ \\
\hline \multirow[t]{2}{*}{ 7-11 bulan } & Tidak depresi & 0 & $0 \%$ \\
\hline & Depresi & 1 & $100 \%$ \\
\hline \multirow[t]{2}{*}{ 1-3 tahun } & Tidak depresi & 2 & $16,7 \%$ \\
\hline & Depresi & 10 & $83,3 \%$ \\
\hline \multirow[t]{2}{*}{ 4-8 tahun } & Tidak depresi & 3 & $33,3 \%$ \\
\hline & Depresi & 6 & $66,7 \%$ \\
\hline \multicolumn{4}{|l|}{ Honorarium } \\
\hline \multirow[t]{2}{*}{$<500000$} & Tidak depresi & 5 & $18,5 \%$ \\
\hline & Depresi & 22 & $81,5 \%$ \\
\hline \multirow[t]{2}{*}{ 500000-1000000 } & Tidak depresi & 0 & $0 \%$ \\
\hline & Depresi & 2 & $100 \%$ \\
\hline \multirow[t]{2}{*}{$>1000000$} & Tidak depresi & 0 & $0 \%$ \\
\hline & Depresi & 1 & $100 \%$ \\
\hline \multicolumn{4}{|l|}{$\begin{array}{l}\text { Pendapatan } \\
\text { tambahan }\end{array}$} \\
\hline \multirow[t]{2}{*}{ Tidak } & Tidak depresi & 2 & $13,3 \%$ \\
\hline & Depresi & 13 & $86,7 \%$ \\
\hline \multirow[t]{2}{*}{$\mathrm{Ya}$} & Tidak depresi & 3 & $20 \%$ \\
\hline & Depresi & 12 & $80 \%$ \\
\hline \multicolumn{4}{|l|}{ Jam kerja/hari } \\
\hline \multirow[t]{2}{*}{ 1-3 jam } & Tidak depresi & 1 & $5,9 \%$ \\
\hline & Depresi & 16 & $94,1 \%$ \\
\hline \multirow[t]{2}{*}{ 4-6 jam } & Tidak depresi & 4 & $30,8 \%$ \\
\hline & Depresi & 9 & $69,2 \%$ \\
\hline
\end{tabular}

Tabel 5. Kejadian depresi berdasarkan Kecamatan di Kec. Kotamobagu Barat

\begin{tabular}{|c|c|c|c|}
\hline Variabel & & $\mathbf{n}$ & $\%$ \\
\hline \multicolumn{4}{|l|}{ Umur } \\
\hline \multirow[t]{2}{*}{$17-25$} & Tidak depresi & 3 & $33,3 \%$ \\
\hline & Depresi & 6 & $66,7 \%$ \\
\hline \multirow[t]{2}{*}{$26-34$} & Tidak depresi & 1 & $6,3 \%$ \\
\hline & Depresi & 15 & $93,8 \%$ \\
\hline \multirow[t]{2}{*}{$35-43$} & Tidak depresi & 0 & $0 \%$ \\
\hline & Depresi & 6 & $100 \%$ \\
\hline \multicolumn{4}{|l|}{ Jenis kelamin } \\
\hline \multirow[t]{2}{*}{ Perempuan } & Tidak depresi & 5 & $17,2 \%$ \\
\hline & Depresi & 24 & $82,8 \%$ \\
\hline \multicolumn{4}{|l|}{$\begin{array}{l}\text { Status } \\
\text { pernikahan }\end{array}$} \\
\hline \multirow[t]{2}{*}{ Belum menikah } & Tidak depresi & 3 & $37,5 \%$ \\
\hline & Depresi & 5 & $62,5 \%$ \\
\hline \multirow[t]{2}{*}{ Menikah } & Tidak depresi & 1 & $5,6 \%$ \\
\hline & Depresi & 17 & $94,4 \%$ \\
\hline \multirow[t]{2}{*}{ Cerai hidup } & Tidak depresi & 1 & $33,3 \%$ \\
\hline & Depresi & 2 & $66,7 \%$ \\
\hline \multicolumn{4}{|l|}{ Masa kerja } \\
\hline \multirow[t]{2}{*}{ 3-6 bulan } & Tidak depresi & 2 & $66,7 \%$ \\
\hline & Depresi & 1 & $33,3 \%$ \\
\hline \multirow[t]{2}{*}{ 7-11 bulan } & Tidak depresi & 0 & $0 \%$ \\
\hline & Depresi & 1 & $100 \%$ \\
\hline \multirow[t]{2}{*}{ 1-3 tahun } & Tidak depresi & 3 & $25 \%$ \\
\hline & Depresi & 9 & $75 \%$ \\
\hline \multirow[t]{2}{*}{ 4-8 tahun } & Tidak depresi & 0 & $0 \%$ \\
\hline & Depresi & 12 & $100 \%$ \\
\hline \multirow[t]{2}{*}{ 9-12 tahun } & Tidak depresi & 0 & $0 \%$ \\
\hline & Depresi & 1 & $100 \%$ \\
\hline \multicolumn{4}{|l|}{ Honorarium } \\
\hline \multirow[t]{2}{*}{$<500000$} & Tidak depresi & 5 & $23,8 \%$ \\
\hline & Depresi & 16 & $76,2 \%$ \\
\hline \multirow[t]{2}{*}{$500000-1000000$} & Tidak depresi & 0 & $0 \%$ \\
\hline & Depresi & 7 & $100 \%$ \\
\hline \multirow[t]{2}{*}{$>1000000$} & Tidak depresi & 0 & $0 \%$ \\
\hline & Depresi & 1 & $100 \%$ \\
\hline \multicolumn{4}{|l|}{$\begin{array}{l}\text { Pendapatan } \\
\text { tambahan }\end{array}$} \\
\hline \multirow[t]{2}{*}{ Tidak } & Tidak depresi & 4 & $16,7 \%$ \\
\hline & Depresi & 20 & $83,3 \%$ \\
\hline \multirow[t]{2}{*}{$\mathrm{Ya}$} & Tidak depresi & 1 & $20 \%$ \\
\hline & Depresi & 4 & $80 \%$ \\
\hline \multicolumn{4}{|l|}{ Jam kerja/hari } \\
\hline 1-3 jam & Tidak depresi & 2 & $13,3 \%$ \\
\hline & Depresi & 13 & $86,7 \%$ \\
\hline 4-6 jam & Tidak depresi & 3 & $21,4 \%$ \\
\hline & Depresi & 11 & $78,6 \%$ \\
\hline
\end{tabular}


Tabel 6. Kejadian depresi berdasarkan Kecamatan di Kec. Kotamobagu Timur

\begin{tabular}{|c|c|c|c|}
\hline Variabel & & $\mathbf{n}$ & $\%$ \\
\hline \multicolumn{4}{|l|}{ Umur } \\
\hline \multirow[t]{2}{*}{$17-25$} & Tidak depresi & 4 & $30,8 \%$ \\
\hline & Depresi & 9 & $69,2 \%$ \\
\hline \multirow[t]{2}{*}{$26-34$} & Tidak depresi & 1 & $6,3 \%$ \\
\hline & Depresi & 15 & $93,8 \%$ \\
\hline \multirow[t]{2}{*}{$35-43$} & Tidak depresi & 0 & $0 \%$ \\
\hline & Depresi & 4 & $100 \%$ \\
\hline \multicolumn{4}{|l|}{ Jenis kelamin } \\
\hline \multirow[t]{2}{*}{ Laki-laki } & Tidak depresi & 0 & $0 \%$ \\
\hline & Depresi & 7 & $100 \%$ \\
\hline \multirow[t]{2}{*}{ Perempuan } & Tidak depresi & 5 & $19,2 \%$ \\
\hline & Depresi & 21 & $80,8 \%$ \\
\hline \multicolumn{4}{|l|}{$\begin{array}{l}\text { Status } \\
\text { pernikahan }\end{array}$} \\
\hline \multirow[t]{2}{*}{ Belum menikah } & Tidak depresi & 3 & $23,1 \%$ \\
\hline & Depresi & 10 & $76,9 \%$ \\
\hline \multirow[t]{2}{*}{ Menikah } & Tidak depresi & 2 & $10,5 \%$ \\
\hline & Depresi & 17 & $89,5 \%$ \\
\hline \multirow[t]{2}{*}{ Cerai hidup } & Tidak depresi & 0 & $0 \%$ \\
\hline & Depresi & 1 & $100 \%$ \\
\hline \multicolumn{4}{|l|}{ Masa kerja } \\
\hline \multirow[t]{2}{*}{ 3-6 bulan } & Tidak depresi & 0 & $0 \%$ \\
\hline & Depresi & 2 & $100 \%$ \\
\hline \multirow[t]{2}{*}{ 7-11 bulan } & Tidak depresi & 1 & $100 \%$ \\
\hline & Depresi & 0 & $0 \%$ \\
\hline \multirow[t]{2}{*}{ 1-3 tahun } & Tidak depresi & 2 & $12,5 \%$ \\
\hline & Depresi & 14 & $87,5 \%$ \\
\hline \multirow[t]{2}{*}{ 4-8 tahun } & Tidak depresi & 2 & $16,7 \%$ \\
\hline & Depresi & 10 & $83,3 \%$ \\
\hline \multirow[t]{2}{*}{ 9-12 tahun } & Tidak depresi & 0 & $0 \%$ \\
\hline & Depresi & 1 & $100 \%$ \\
\hline \multirow[t]{2}{*}{$>16$ tahun } & Tidak depresi & 0 & $0 \%$ \\
\hline & Depresi & 1 & $100 \%$ \\
\hline \multicolumn{4}{|l|}{ Honorarium } \\
\hline \multirow[t]{2}{*}{$<500000$} & Tidak depresi & 4 & $14,3 \%$ \\
\hline & Depresi & 24 & $85,7 \%$ \\
\hline \multirow[t]{2}{*}{ 500000-1000000 } & Tidak depresi & 1 & $33,3 \%$ \\
\hline & Depresi & 2 & $66,7 \%$ \\
\hline \multirow[t]{2}{*}{$>1000000$} & Tidak depresi & 0 & $0 \%$ \\
\hline & Depresi & 2 & $100 \%$ \\
\hline \multicolumn{4}{|l|}{$\begin{array}{l}\text { Pendapatan } \\
\text { tambahan }\end{array}$} \\
\hline Tidak & Tidak depresi & 3 & $14,3 \%$ \\
\hline & Depresi & 18 & $85,7 \%$ \\
\hline $\mathrm{Ya}$ & Tidak depresi & 2 & $16,7 \%$ \\
\hline & Depresi & 10 & $83,3 \%$ \\
\hline Jam kerja/hari & Tidak depresi & 1 & $5,9 \%$ \\
\hline 1-3 jam & Depresi & 16 & $94,1 \%$ \\
\hline & Tidak depresi & 4 & $25 \%$ \\
\hline 4-6 jam & Depresi & 12 & $75 \%$ \\
\hline
\end{tabular}

Tabel 7. Hasil analisis bivariat perbandingan kejadian depresi

\begin{tabular}{lcccc}
\hline & $\mathbf{n}(\mathbf{\%})$ & $\begin{array}{c}\boldsymbol{X} \mathbf{2} \\
\text { hitung }\end{array}$ & $\begin{array}{c}\text { X2 } \\
\text { Tabel }\end{array}$ & $\boldsymbol{p}$ \\
\hline $\begin{array}{l}\text { Kejadian } \\
\text { depresi }\end{array}$ & & 0,141 & 7,815 & 0,986 \\
\hline $\begin{array}{l}\text { Kotamobagu } \\
\text { Utara }\end{array}$ & $\begin{array}{c} \\
(80 \%)\end{array}$ & & & \\
\hline $\begin{array}{l}\text { Kotamobagu } \\
\text { Selatan }\end{array}$ & 25 \\
$(83,3 \%)$ & & & \\
\hline Kotamobagu & 24 & & & \\
Barat & $(82,8 \%)$ & & & \\
\hline Kotamobagu & 28 & & & \\
Timur & $(84,8 \%)$ & & & \\
\hline
\end{tabular}

Berdasarkan Tabel 5 di Kecamatan Kotamobagu Barat, perempuan juga dominan mengalami depresi daripada laki-laki (24\%), berdasarkan kategori umur, kelompok dengan usia 26-34 tahun dan sudah menikah cenderung mengalami depresi. Dilihat dari masa kerja dan jumlah honorarium per bulan, maka individu yang mengabdi selama 4-8 tahun dan dengan honor $<$ Rp.500.000 yang rentan mengalami depresi.Berdasarkan pendapatan tambahan dan jam kerja/hari, maka yang tidak memiliki pendapatan tambahan di luar honorer serta yang memilki jam kerja 1-3 jam/hari cenderung mengalami depresi.

Berdasarkan tabel 6 di Kecamatan Kotamobagu Timur, perempuan lebih rentan mengalami depresi daripada laki-laki (80.8\%), berdasarkan kategori umur dan status pernikahan, maka usia di antara 26-34 tahun dan sudah menikah yang lebih rentan mengalami depresi. Berdasarkan masa kerja dan honorarium yang diterima, maka yang memiliki masa kerja 1-3 tahun dan yang mendapat honorarium <Rp.500.000/bulan yang cenderung mengalami depresi.Sedangkan ada atau tidaknya pendapatan tambahan dan jam kerja/hari maka yang tidak memiliki pendapatan tambahan di luar honorer serta memiliki jam kerja 1-3 jam yang cenderung mengalami depresi. 
Tabel 8. Hasil analisis bivariat tingkat depresi

\begin{tabular}{|c|c|c|c|c|c|}
\hline \multicolumn{2}{|c|}{ Kotamobagu } & $\begin{array}{c}n \\
(\%)\end{array}$ & $\begin{array}{l}\text { X2 } \\
\text { hitung }\end{array}$ & $\begin{array}{l}\text { X2 } \\
\text { tabel }\end{array}$ & $p$ \\
\hline \multicolumn{2}{|l|}{$\begin{array}{l}\text { Tingkat } \\
\text { depresi }\end{array}$} & & 2,163 & 16,99 & $\begin{array}{c}0,98 \\
9\end{array}$ \\
\hline \multirow{4}{*}{ Ringan } & Utara & $\begin{array}{c}4 \\
(40 \%)\end{array}$ & & & \\
\hline & Selatan & $\begin{array}{c}18 \\
(60 \%)\end{array}$ & & & \\
\hline & Barat & $\begin{array}{c}17 \\
(58,6 \%)\end{array}$ & & & \\
\hline & Timur & $\begin{array}{c}20 \\
(60,6 \%)\end{array}$ & & & \\
\hline \multirow{4}{*}{ Sedang } & Utara & $\begin{array}{c}3 \\
(30 \%)\end{array}$ & & & \\
\hline & Selatan & 6 & & & \\
\hline & Barat & $\begin{array}{c}6 \\
(20,7 \%)\end{array}$ & & & \\
\hline & Timur & $\begin{array}{c}6 \\
(18,2 \%)\end{array}$ & & & \\
\hline \multirow{4}{*}{ Berat } & Utara & $\begin{array}{c}1 \\
(10 \%)\end{array}$ & & & \\
\hline & Selatan & $\begin{array}{c}1 \\
(3.3 \%)\end{array}$ & & & \\
\hline & Barat & $\begin{array}{c}1 \\
(3,4 \%)\end{array}$ & & & \\
\hline & Timur & $\begin{array}{c}2 \\
(6,1 \%)\end{array}$ & & & \\
\hline
\end{tabular}

Berdasarkan analisis menggunakan pearson Chi square (lihat tabel 7 dan 8) untuk mencari adanya perbedaan kejadian maupun tingkat depresi didapatkan hasil nilai $\mathrm{p}=0,986(\mathrm{p}>0,05)$ untuk perbandingan kejadian depresi dan $\mathrm{p}=0,989 \quad(\mathrm{p}>0,05)$ untuk perbandingan tingkat depresi pada masing-masing Kecamatan. Dari hasil tersebut didapatkan tidak ada perbedaan yang bermakna untuk perbandingan kejadian dan tingkat depresi guru honorer di empat Kecamatan di Kota Kotamobagu Provinsi Sulawesi Utara. Hal ini terjadi karena rerata jumlah kejadian dan tingkat depresinya sama atau tidak berbeda jauh sehingga hampir tidak ada perbedaa yang bermakna.

Terdapat penelitian sebelumnya namun dengan dengan subjek guru yang tidak spesifik guru tetap atau guru bantu yang dilakukan oleh Dolores, dan kawan-kawan menemukan adanya hubungan yang bermakna antara jenis kelamin dengan kejadian depresi yang terjadi pada guru $(p=0,01)$ yang mana secara spesifik gejala depresi lebih dominan terjadi pada perempuan dibandingkan dengan laki-laki dalam hal prevalensi depresi pada keseluruhan populasi umum. ${ }^{15,16}$ Sesuai dengan teori sebelumnya, tingginya prevalensi depresi pada perempuan disebabkan masalah kepribadian seperti neurotisme. $^{17}$ Penyebab lain yaitu perubahan faktor hormonal dan faktor psikologis yang disebabkan dari tekanan pekerjaan yang ditekuninya. ${ }^{18}$

Berdasarkan penelitian tersebut juga ditemukan hubungan yang bermakna antara umur dengan gejala depresi pada guru $(p=0,0053)^{15}$, secara spesifik umur telah diamati dan dikaitkan dengan meningkat atau menurunnya tingkat depresi. ${ }^{16,17}$ Pada penelitian tersebut diamati guru dengan usia >30 tahun merupakan faktor risiko yang bersifat independen untuk terjadinya depresi. $^{15}$ Jika dilihat teori sebelumnya kategori umur tidak menentukan secara pasti individu dapat terhindar dari depresi, karena semua kategori umur memiliki risiko yang sama untuk mengalami depresi, adapun onset terjadinya depresi biasanya pada umur 20-40 tahun. ${ }^{19}$ Berdasarkan kenyataan di lapangan, guru honorer di Kota Kotamobagu rerata terdapat pada kelompok umur tersebut, hal itu terjadi kemungkinan karena guru-guru honorer yang terdaftar lebih banyak pada kelompok usia tersebut dan bertepatan didapatkan mengalami depresi saat pengisian kuesioner.

Pada penelitian tersebut juga dilihat dari status perkawinan yang dikaitkan dengan depresi, ternyata status perkawinan memengaruhi hasil CES-D/The Center For Epidemiologic Studies Depression Score namun tidak terhadap prevalensi gejala depresi. ${ }^{15}$ Penelitian lain yang dilakukan Smith,dan kawan-kawan menyatakan adanya korelasi antara status pernikahan dengan kejadian stres yang dialami oleh guru, yang mana stres akan lebih sering dilaporkan pada mereka yang bercerai, janda, atau berpisah, sedangkan penelitian lain yang dilakukan oleh Yahaya,dan kawan-kawan dan Roxas membantah hasil tersebut yakni tidak ada perbedaan yang 
bermakna antara level stres yang dialami dengan status pernikahan yang dimiliki guru. ${ }^{20}$

Teori sebelumnya menyatakan status pernikahan merupakan salah satu faktor penentu terjadinya depresi, yang mana depresi lebih rentan terjadi pada seseorang yang memiliki hubungan interpersonal yang kurang, misalnya bercerai atau berpisah dan cenderung jarang terjadi pada yang sudah menikah atau berstatus lajang. ${ }^{19,21}$ Berdasarkan kondisi guru honorer pada penelitian ini, maka yang berstatus menikah lebih banyak yang mengalami depresi, keadaan ini menjadi perhatian khusus dalam pembahasan ini. Guru honorer yang dengan status kepegawaian yang tidak jelas dan serba kekurangan dalam hal pendapatan sebagai honorer, memiliki tanggung jawab khusus untuk menghidupi keluarganya.Hal ini menjadi sumber stres tersendiri bagi mereka baik laki-laki ataupun perempuan dibandingkan dengan yang masih berstatus lajang, memiliki keluarga berarti individu tersebut harus siap mengemban tanggung jawab baik secara materiil maupun spiritual.

Masa kerja, honorarium per bulan, pendapatan tambahan, serta jam kerja merupakan faktor-faktor yang sangat sensitif untuk menggambarkan rentannya seorang guru honorer mengalami depresi beserta tingkatannya baik ringan, sedang, maupun berat. Penelitian sebelumnya yang dilakukan oleh Ariani pada tahun 2009 didapatkan guru honorer pada umumya paling banyak berada pada kelompok masa kerja 6-10 tahun (46,87\%) dengan honor terendah perbulan sebesar Rp.312.000 dan tertinggi Rp. 780.000, yang mana dengan gaji sekecil itu di masa kondisi ekonomi yang terpuruk saat ini, gaji tersebut tidak dapat memenuhi kebutuhan hidup mereka sehari-hari, oleh karena itu, sebagian besar guru honorer di Sekolah tersebut memiliki tempat mengajar lain dan memiliki usaha sampingan. $^{22}$

Penelitian sebelumnya mencoba mengaitkan hubungan masa kerja dan gaji rerata jam mengajar untuk 1 bulan berkisar antara 12-30 jam/bulan.yang dimiliki guru.
Rerata guru yang memiliki pengalaman atau masa kerja dalam mengajar di antara 6-10 tahun atau lebih cenderung mengalami stres dalam pekerjaannya $(\mathrm{M}=55,11, \mathrm{SD}=16,53)$ daripada kelompok masa kerja di bawah 6-10 tahun. $^{20}$ Stres pekerjaan yang bersifat negatif menjadi prediktor terjadinya depresi pada guru yang mana depresi memiliki hubungan yang bermakna dengan kepuasan kerja. Berdasarkan penelitian tersebut, pengalaman kerja atau masa kerja yang dimiliki merupakan prediktor positif terhadap kepuasan kerja, semakin banyaknya pengalaman dan kemampuan terhadap pekerjaan yang ditekuni maka pada saat itu kepuasan kerja meningkat, namun apabila ada prediktor negatif yang memengaruhi pekerjaan tersebut seperti depresi maka kepuasan kerja menjadi menurun. ${ }^{23}$ Dari segi gaji yang didapatkan guru honorer, seperti pada penelitian Ariani tahun 2009, terdapat pengaruh yang positif antara gaji dengan komitmen seorang guru honorer, hal ini terlihat dari nilai bermaknasi $(0,000)<0,05$ dan nilai t hitung $(5,481)>t$ tabel (1,96), intinya bila dilakukan peningkatan gaji akan memberi dampak positif terhadap komitmen. ${ }^{22}$

Dari penelitian ini, depresi yang dialami guru honorer tidak terpaku pada satu kelompok masa kerja saja.Adanya perasaan depresi menunjukkan ketidaknyamanan dari profesi tersebut, namunyang menjadi persoalan dalam situasi tersebut seorang guru honorer dengan status demikian masih dapat mengajar dan mempertahankan profesinya. Menurut Kyriacou, ada sejumlah mekanisme coping yang seorang guru lakukan sehubungan dengan stres atau depresi yang dialami yaitu direct action techniques dan paliative techniques. Inti dari keseluruhan teknik tersebut yakni tetap menghadapi persoalan yang ada, menolak konfrontasi, mencoba untuk relax setelah bekerja, mencari solusi atas persoalan, menjaga perasaan agar tetap terkontrol, memiliki keluarga yang baik serta menyadari keterbatasan yang dimiliki. $^{24}$

Penelitian ini mempunyai kelemahan antara lain, pada pembagian kuesioner tidak 
ditambahkan pertanyaan seputar persepsi guru honorer dengan kondisi pekerjaan yang dimilikinya seperti stres pekerjaan, hubungan dengan siswa maupun relasi di sekolah.dan lain-lain. Hal itu sangat penting untuk ditanyakan, agar diketahui apakah depresi yang dialami guru honorer memang benar-benar disebabkan statusnya oleh guru honorer atau ada faktor lain yang memengaruhi. Selain itu penelitian ini secara statistik tidak menghubungkan variabel-variabel independen yang ada dengan variabel dependen yaitu depresi untuk mencari hubungan atau pengaruhnya, karena fokus penelitian ini hanya untuk menilai perbandingan prevalensi depresi dari empat Kecamatan.

\section{SIMPULAN DAN SARAN}

Berdasarkan hasil penelitian dan pembahasan maka dapat diambil simpulan yakni; tingginya angka kejadian depresi responden berdasarkan persentase tiap kecamatan, di Kecamatan Kotamobagu Utara ialah 80\%, di Kecamatan Kotamobagu Selatan 83,3\%, di Kecamatan Kotamobagu Barat $82.8 \%$ dan di Kecamatan Kotamobagu Timur 84,8\%.

Tingkat depresi berdasarkan persentase tiap Kecamatan, di Kecamatan Kotamobagu Utara depresi ringan sebesar $40 \%$, depresi sedang 30\%, dan depresi berat 10\%. Di Kecamatan Kotamobagu Selatan, depresi ringan sebesar $60 \%$, depresi sedang $20 \%$, dan depresi berat 3,3\%. Di Kecamatan Kotamobagu Barat depresi ringan sebesar 58,6\%, depresi sedang 20,7\% dan depresi berat 3,4\%. Dan di Kecamatan Kotamobagu Timur depresi ringan sebesar $60,6 \%$, depresi sedang $18,2 \%$ dan depresi berat $6,1 \%$.

Tidak ada perbedaan yang bermakna antara kejadian maupun tingkat depresi guru honorer di Sekolah Dasar Negeri pada empat Kecamatan di Kota Kotamobagu, dengan hasil nilai $p=0,986(p>0,05)$ untuk perbandingan kejadian depresi dan $\mathrm{p}=0,989$ $(p>0,05)$ untuk perbandingan tingkat depresi pada masing-masing Kecamatan.

Berdasarkan hasil yang didapat mengenai kejadian dan tingkat depresi dari empat Kecamatan,diharapkan Pemerintah setempat lebih memerhatikan kesejahteraan guru honorer dengan memperbaiki status kepegawaiannya sehingga dengan tercapainya tujuan tersebut kehidupan guru honorer menjadi lebih baik.

\section{UCAPAN TERIMA KASIH}

Pembimbing I dan II dan kepada semua pihak yang secara langsung maupun tidak langsung dalam menumbuhkan gagasan dalam penulisan artikel ini.

\section{DAFTAR PUSTAKA}

1. Pusat Bahasa Departemen Pendidikan Nasional. Kamus besar bahasa Indonesia. Edisi 3. Jakarta: Balai Pustaka; 2001.h. 330

2. Direktorat Jenderal Pendidikan Tinggi. Undang-undang Republik Indonesia nomor 14 tahun 2005 tentang guru dan dosen.2011. [diakses pada 7 November 2012]. Available from: http://www.dikti.go.id/ files/atur/UU14-2005GuruDosen.pdf

3. Disesalkan Guru Honorer Tidak Punya Hak Sertifikasi. Suara Merdeka [Internet]. 28 November 2012. [Diakses pada tanggal 1 Desember 2012]. Available from:

http://www.suaramerdeka.com/v1/index.php/ read/cetak/2012/11/29/207063/Disesalkan-G uru-Honorer-Tak-Punya-Hak-Sertifikasi

4. Guru Honorer Dalam Jaminan Sosial. Koran Pendidikan [Internet]. 6 November 2012 [Diakses pada tanggal 1 Desember 2012]. Available

from: http://www.koranpendidikan.com/vie w/2175/guru-honorer-dalam-jaminan-sosial .html

5. Masalah Guru Honorer Masih Juga Belum Tuntas. Fokus Riau [Internet]. 3 November 2012 [Diakses pada tanggal 1 Desember 2012].

Available

from: http://fokusriau.com/berita-1422-mas alah-guru-honorer-masih-belum-jelas-jugatuntas-.html

6. Maslim R. Diagnosis gangguan jiwa rujukan ringkas dari PPDGJ-III. Jakarta: Bagian Ilmu Kedokteran Jiwa FK-Unika Atmajaya; 2003.

7. Poongothai S, Pradeepa R, Ganesan A, Mohan V. Prevalence of depression in a large urban South Indian population - the 
Chennai urban rural epidemiology study (cures -70). Journal Plos One. 2009;4:1-6

8. Lubis NL. Depresi tinjauan psikologis. Jakarta: Kencana Prenada Media Group; 2009.

9. Kyriacou C. Teacher stress: Direction fo future research. Educational Review. 2001;53;27

10. Schonfeld IS. A longitudinal study of occupational stressors and depressive symptoms in first-year female teachers. Teaching \& Teacher Education. 1992; 8:151-158.

11. European Agency for Safety and Health at Work. Prevention of work-related stress in the education sector. E-fact 31. 2008 [diakses pada 10 Oktober 2012] Available from: http://osha.europa.eu/en/publications/ e-facts/efact31/view

12. Mary A. Chronic Work Stress and Depression: Assessing the Mediating Role of Teacher Burnout [internet]. 2010 [diakses pada 21 Oktober 2012]. Available from: http://www.edb.utexas.edu/ steinhardt/Researchchronicstress.html

13. National Center for Education Statistics. The condition of education. Washington, D.C: U.S. Government Printing Office.1998. h. 3

14. Padmawati. Kajian yuridis status hukum tenaga guru honorer pemerintah kota Surakarta pada dinas pendidikan pemuda dan olahraga kota Surakarta menurut undang-undang Nomor 43 tahun 1999 tentang pokok-pokok kepegawaian. [skripsi]. Surakarta: Fakultas Hukum Universitas Sebelas Maret; 2010.

15. Jurado D, Gurpegui M, Moreno O, Fernandez, MC, Luna JD, Galvez R.
Association of Personality and work conditions with depressive symptoms. European Psychiatry.2005;20:213-222

16. Kessler RC. Epidemiology of women dan depression. J Affect Disord. 2003; 74:5-13

17. Fanous A, Gardner CO, Prescott CA, Cancro R, Kendler RS. Neuroticism, major depression and gender: a population-based twin study. Psychol Med 2002; 32:719-28

18. Mausner-Dor H, Eaton WW. Psychosocial work environment and depression: epidemiologic assessment of the demand-control model. Am J Public Health 2000;90:1765-70

19. Haggerty J. Risk Factors for Depression. Psych Central. 2006. [diakses pada 17 Januari 2013]. Available from: http://psychcentral.com/lib/2006/risk-factor s-for-depression/

20. Aftab M, Khatoon T. Demographic Differences and Occupational Stress of Secondary School Teachers. European Scientific Journal. 2012;8: 159-175

21. Kaplan HI, Sadock BJ, dan Grebb JA. Gangguan mood. Dalam: Sinopsis psikiatri. Jakarta: Bina Rupa Aksara; 2010. h. 227-32.

22. Ariani F. Pengaruh Gaji Terhadap Komitmen Guru Honor Pada Sekolah Menengah Atas (SMA) Swasta Josua Medan. [Skripsi]. Fakultas Ekonomi Universitas Sumatera Utara; 2009.

23. Ferguson K, Frost L, Hall D. Predicting Teacher Anxiety, Depression, and Job Satisfaction. Journal of teaching and learning. 2012;8:27-42

24. Darmody M, Smyth E. Job Satisfaction and Occupational Stress among Primary School Teachers and School Principals in Ireland. Dublin: ESR.201 